\title{
APPROACHES TO OPTIMIZATION OF FUNCTIONING OF CITIES BY ENVIRONMENTAL CRITERIA
}

\author{
O. M. Zagurskiy, A. M. Ohiienko
}

National University of Life and Environmental Sciences of Ukraine, Ukraine.

Speciality of article: 275 - transport technologies (by road).

Corresponding authors: zagurskiy_oleg@ukr.net.

Article history: Received - August 2020, Accepted-October 2020.

Bibl. 18, fig. 7, tabl. 1.

Abstract. The question of efficiency of transport systems is one of the actual questions of present time. Performing the duty from moving loads and providing the various blessing for an economy and population, transport become a source of the strongest contamination of environment simultaneously. Accordingly, to the basic task of "green" logistic, which consists in balancing of ecological and economic problems, in determination of optimal decisions at that at unchanging (or near to them) charges it is sorry inflicted by transport it will be an environment.

The studies about a factor is undertaken in the article, that influence on efficiency of transport systems of cities, especially from the point of view of ecological constituent, and mathematical model have built, that allows to put and decide the task of forming and optimizations of functioning of transport systems of cities. Realizable practical development of complex algorithms that give an opportunity to expect the parameters of transpor- ecological processes, that is optimized with the aim of reduction of ecological contamination of city.

Influence of a transport factor on the environment of city is considered on the example of city Mykolaiv, that has the wide, powerful system of transport, permanent freight and passenger streams and middle level of ecological contamination. For the complex decision of transport- ecological problems cities are applied approach is built on a pine methods of the dynamic programming and imitation design. His application does possible to put a task to optimization of functions of traffic control on the backbone network of transport highways with the different degree of working out on detail of municipal.

Key words: economy, environmental friendliness, routing, optimization, harmful emissions.

\section{Introduction}

The issue of transport system efficiency is one of the most pressing issues of today. While performing its function of moving goods and providing various benefits for the economy and the population, transport on the same time is one of the sources of the most serious environmental pollution. It is the main acoustic disturbance and pollutant of the atmosphere and hydrosphere. According to estimates by foreign experts, transport accounts for more than $24 \%$ of the total carbon dioxide emissions on the planet [16], 27\% of greenhouse gas emissions [11]. Transportation is also a major source of NOx, SOx, and particulate matter or fine dust [15].

\section{Formulation of problem}

The motor transport is a leader among other modes of transport. It is a major air pollutant associated with: large quantities of exhaust gas, solid emissions, excessive noise, vibration waves, dust generated by wear and tear, etc. In this regard, the introduction of "green" technologies at any stage of transport and logistics activities will make a significant contribution to maintaining the climate on the planet, suitable for human life.

\section{Analysis of recent research results}

The analysis of scientific literature showed that in general understanding of the essence of "green" logistics formed, defined principles and system of indicators of environmental effect of logistics activities, which testifies to the formation and development of the concept of "green" logistics. And if the main function of traditional logistics is to coordinate all types of logistics activities to meet the needs of customers with minimal cost [10], in green logistics, companies pay more attention to external externalities related to climate change, air, water and soil pollution. in order to strike a sustainable balance between the economy, the environment and society.

In recent years, problems of "green logistics" have been given sufficient attention by both foreign and domestic scientists $[5 ; 12 ; 14]$ and many others.

For the purposes of our study, we identify those that are directly related to research on the environmental impact of transportation for residents and ways of overcoming it. Among these studies, the work of M. Averkina [1], A. Hnatov, Shch Argun, and O Ulyanets [2; 3], O. Stepanchuk and A. Belyatinsky 
[8], S. Bellekom [9], W. Xiaogang, H. Chen and Ch Jingfu [13].

\section{Purpose of research}

The purpose of the study is to learn the factors that affect the efficiency of urban transport systems, especially from the point of view of the environmental component, and to build a mathematical model that allows to set and solve the problems of forming and optimizing the functioning of urban transport systems. Practical development of a set of algorithms that allow to calculate the parameters of transport-ecological processes optimized to reduce the environmental pollution of the city.

\section{Results of research}

The influence of the transport transport factor on the environment of the city is examined by the example of the city of Mykolaiv, which has a wide, powerful transport system, which has included into its system all types of transport.

Mykolaiv region is an important center of national and international transport complexes. The length of solid roads is more than 4.8 thousand $\mathrm{km}$.

Considering the indicator of freight traffic of road transport in Nikolaev and the region. (Fig. 1) we note that from 2010 to 2018, no significant changes occurred, with each year the turnover slowly increased.
Freight traffic by road

5000000

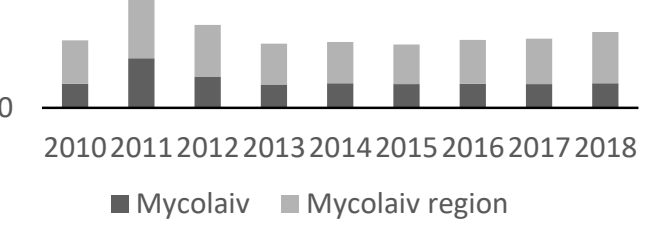

Fig. 1. Freight traffic by road, thousand tons.

Source: data from the main statistics department data in the Mykolaiv region URL:http://www.mk.ukrstat. gov.ua.

With the exception of 2011, when the turnover in the city was 1580694 thousand tons, and in the Mykolayiv region it was equal to 2156045 thousand tons, which is $70-80 \%$ above the average.

Analysis of the volume of goods transported by road in the city of Mykolaiv and Mykolaiv region (Table 1) shows that no significant changes have taken place either. Comparing the volume of transportation in 2018 with 2010, one can find an increase in Mykolayiv by 16.9 thousand tons, and a fall in the volume of transportation in the region by 522.2 thousand tons.

Inhabitants of Mycolaiv always took care of the ecological state of the city. The actual distribution of the use of modes of transport in Mykolayiv shows that public and individual transport accounts for $60.9 \%$ of the total (Fig. 2)

Table 1. The volume of goods transported by road, thousand tons.

\begin{tabular}{|l|c|c|c|c|c|c|c|c|c|}
\hline Region & 2010 & 2011 & 2012 & 2013 & 2014 & 2015 & 2016 & 2017 & 2018 \\
\hline $\begin{array}{l}\text { Mycolaiv } \\
\text { region }\end{array}$ & 21866 & 21835 & 20540 & 19469 & 19404 & 19485 & 22971 & 20498 & 21344 \\
\hline Mycolaiv & 7222 & 8374 & 6756 & 6715 & 6611 & 7433 & 7598 & 6797 & 7239 \\
\hline
\end{tabular}

Source: data from the main statistics department data in the Mykolaiv region URL:http://www.mk.ukrstat.gov.ua.

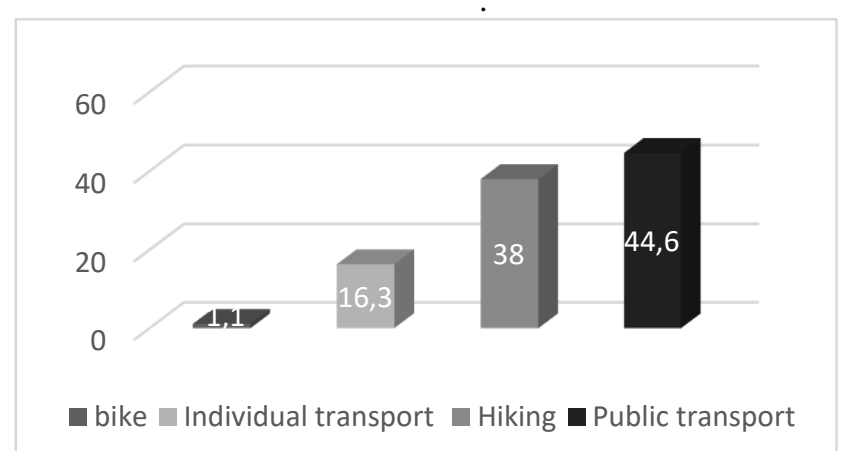

Fig. 2. Current distribution of use of modes of transport in Mykolaiv.

Source: Compiled by the authors.

It should be noted that the Nikolaev area is not included in the list of regions with high pollution of atmosphere in the absence of the enterprises of the chemical and coal industry. Indicators of the level of technogenic load on the environment of the Mykolaiv region are lower than the average in Ukraine. According to the Ecology Department in Mykolaiv region, in 2018, 13,098 thousand tons of atmospheric air from stationary sources of pollution were received, which is $7.6 \%$ (1080 tons) less pollutants than in 2017. This is due to the reduction of emissions during the transportation of methane to the Mykolayiv LWUMG of PJSC "UKRTRANSGAZ" and PJSC "Mykolayivgaz" [6]. The largest share in the structure of hazardous emissions is made by the processing industry $41.4 \%$. Emissions from transport, warehousing, postal and courier activities account for a large proportion, namely $17,7 \%$. Emissions from agriculture, forestry and fisheries account for the smallest share in the cost structure, accounting for $6 \%$. (Fig. 3)

In view of the above, we can say that the amount of emissions into the atmosphere from the operation of transport is quite high and significant in the overall structure. Therefore, control bodies and administrations of the region need to take measures to reduce these 
indicators, which will further improve the environmental status of the city and the region as a whole.

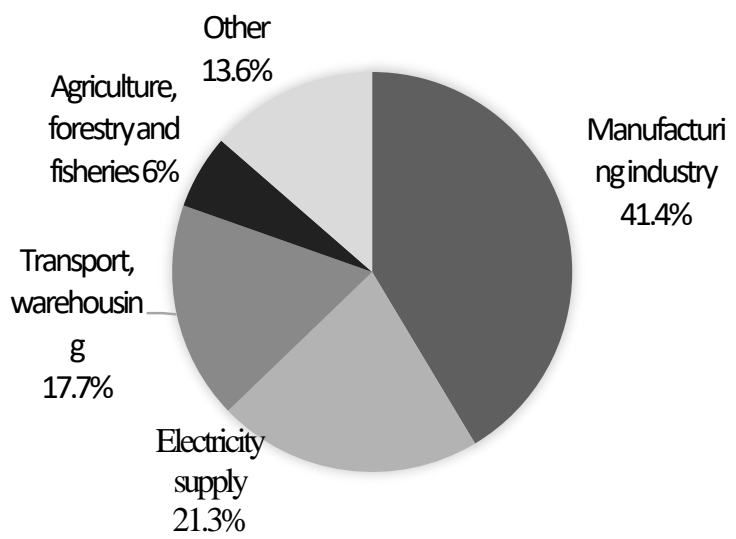

Fig. 3. Emissions of pollutants into the atmosphere by type of economic activity.

Source: data from the main statistics department data in the Mykolaiv region URL:http://www. mk. ukrstat. gov.ua.
The main problem for residents of the city of Nikolaev is the problem of transit traffic. Trucks moving grain crops and industrial loads from Kherson, Odessa, Kiev, Dnipro, Kropyvnytskyi, Mariupol, Zaporizhzhya should pass through the historical center of the city of Nikolaev. Due to the fact that in the south of Ukraine the cities were built densely enough, there are no free corridors in the residential and industrial zones of Mykolayiv for the construction of new motorways. The city has a partial detour that combines roads to Kiev, Kropyvnytskyi, Kryvyi Rih and Kherson, bypassing the road to Odessa sideways (Fig. 4).

Analyzing the scheme of freight transport in Mykolaiv, we can say that the Varvarovsky and Ingulsky bridges, which are bridges of international destination, the historical center of the city is quite loaded, especially a large amount of congestion in the season of grain exports, which leads to a large number of harmful emissions into the atmosphere, melting the road surface from overloaded vehicles.

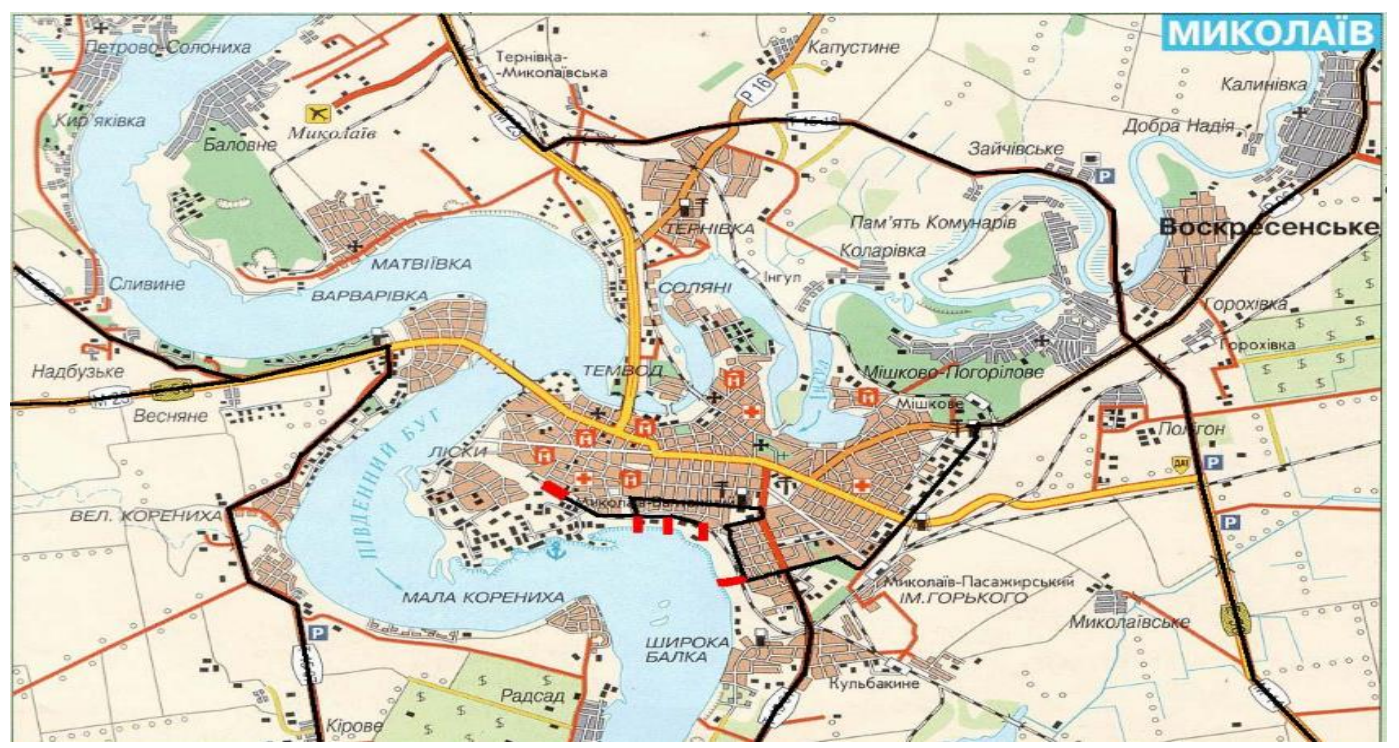

Fig. 4. Scheme of movement of freight transport in Mykolaiv.

Source: project concept: integrated development of Mykolayiv.

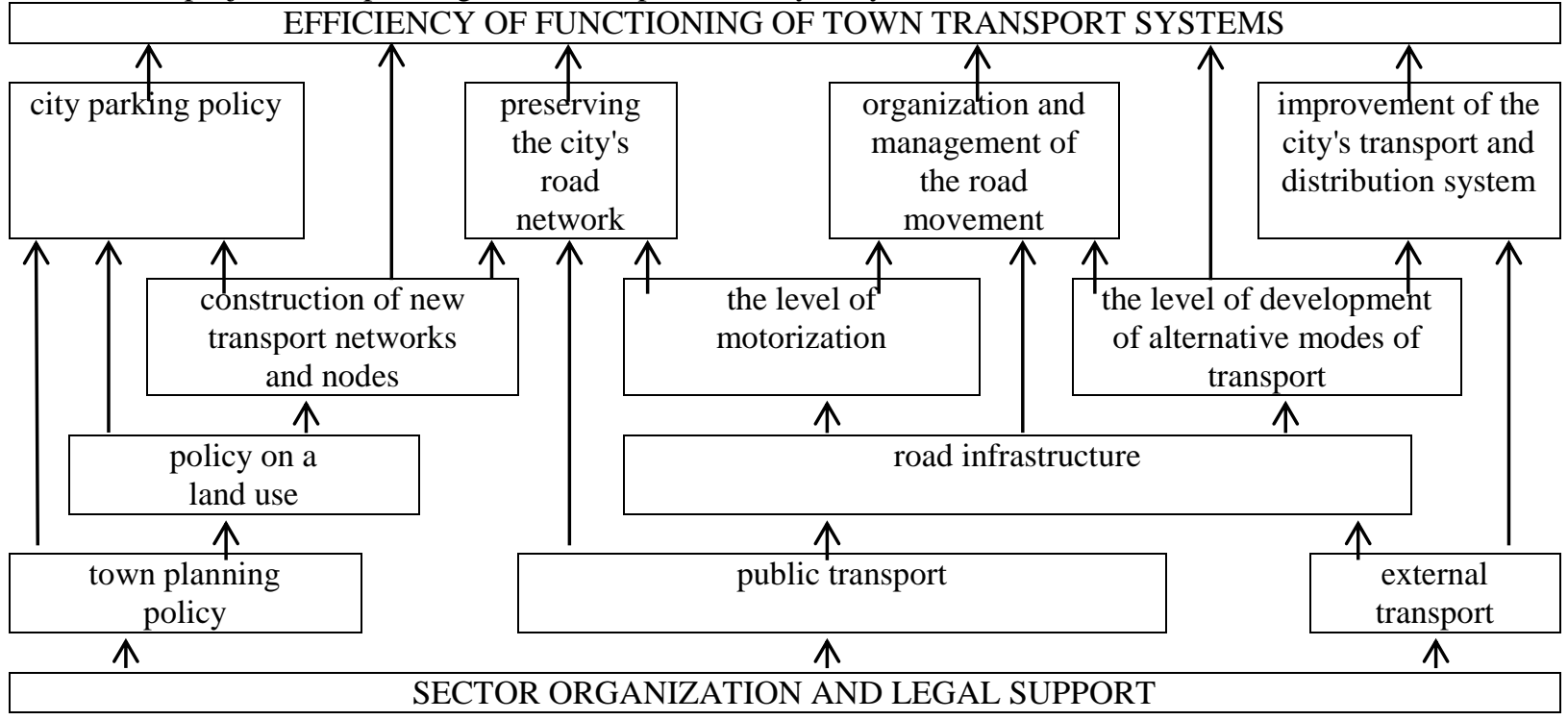

Fig. 5. Factors affecting the performance of SCIs.

Source: Compiled by the authors. 
The complex structure of the relationship between these factors suggests that TGC problems are complex in nature and require a systematic approach to solving them.

However, we note that in addition to the systematic and consistent resolution of these issues, it requires significant financial costs for transport companies and city budgets, which are not always ready to compensate consumers. Therefore, in our opinion, one of the main areas of green logistics is to balance environmental and business (economic) problems. According to L. Gurets, "the basis for solving problems is to develop a logistic concept of freight forwarding services, which is based on routing" [4]. It is to determine the optimal (not worse) solutions for which, at constant (or close to them) costs, environmental damage to the environment will be reduced. Such solutions are called environmental. These include:

- reduction of the total mileage of transport during cargo transportation;

- cargo consolidation, especially for small-shipment cargo ("Less-Than-Truckload" (LTL));
- car sharing;

- routing associated with the calculation of the time of transportation in order to avoid traffic jams and congestion;

- use of environmentally friendly vehicles;

- the inclusion in the transport system of cities of intermediate points of transshipment, in which the movement of goods from large trucks to environmentally friendly city trucks with lower carrying capacity will be carried out.

Taking into account the presence in Mykolayiv of a powerful transport system with passing highways of regional importance, relatively stable freight and passenger flows and the average level of environmental pollution, it is proposed to apply the approach based on pine methods of dynamic and dynamic programming.

Figure 6 shows the scheme of the transport network in Mykolayiv according to which the graph was constructed.

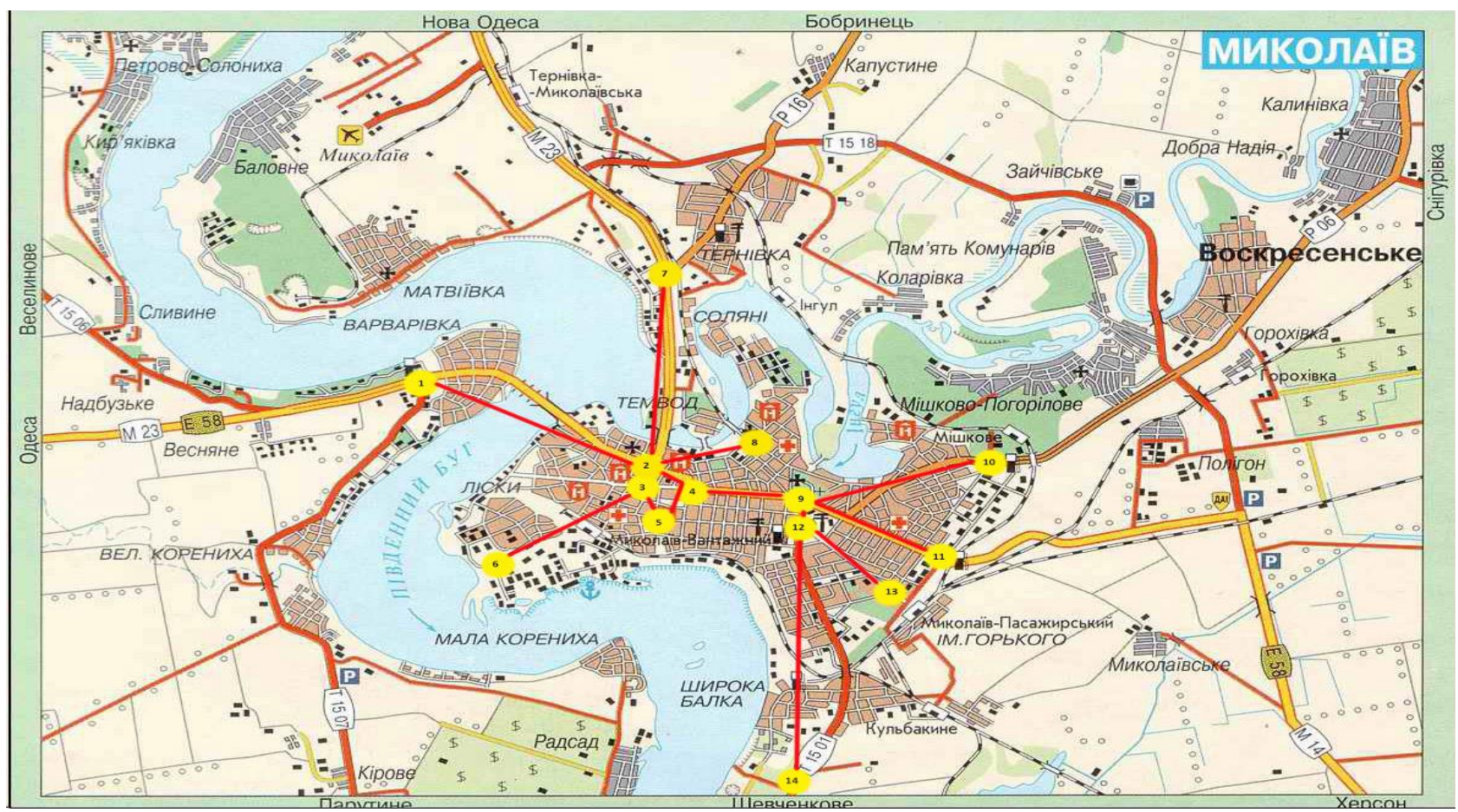

Fig. 6. Scheme of the transport network in Mykolaiv.

In the graph (Fig. 7), the vertices (indicated by circles) represent objects (neighborhoods of the city) having an internal structure. The parameters of these objects determine the level of car traffic between them and, accordingly, the traffic load on the highways. Each such object has its own system of inputs and outputs, and the total inbound traffic is not equal to the output. The second type of vertices, indicated by squares, specifies the control and traffic routing function.

The total traffic on all inputs and outputs of such vertices, for a certain period of time - $\mathrm{T}$ (management period), should be zero. Each such vertex is given by a control function, which, ideally, is periodic in time, but in the general case, the control period can be a discrete function of time. The topology is given by the system connection matrix.

$$
K=\sum_{i=1}^{n} m_{i}+M
$$

where: $n$ - number of cluster vertices;

$m_{i}$ - degree of vertex;

$M$ - number of routing nodes 


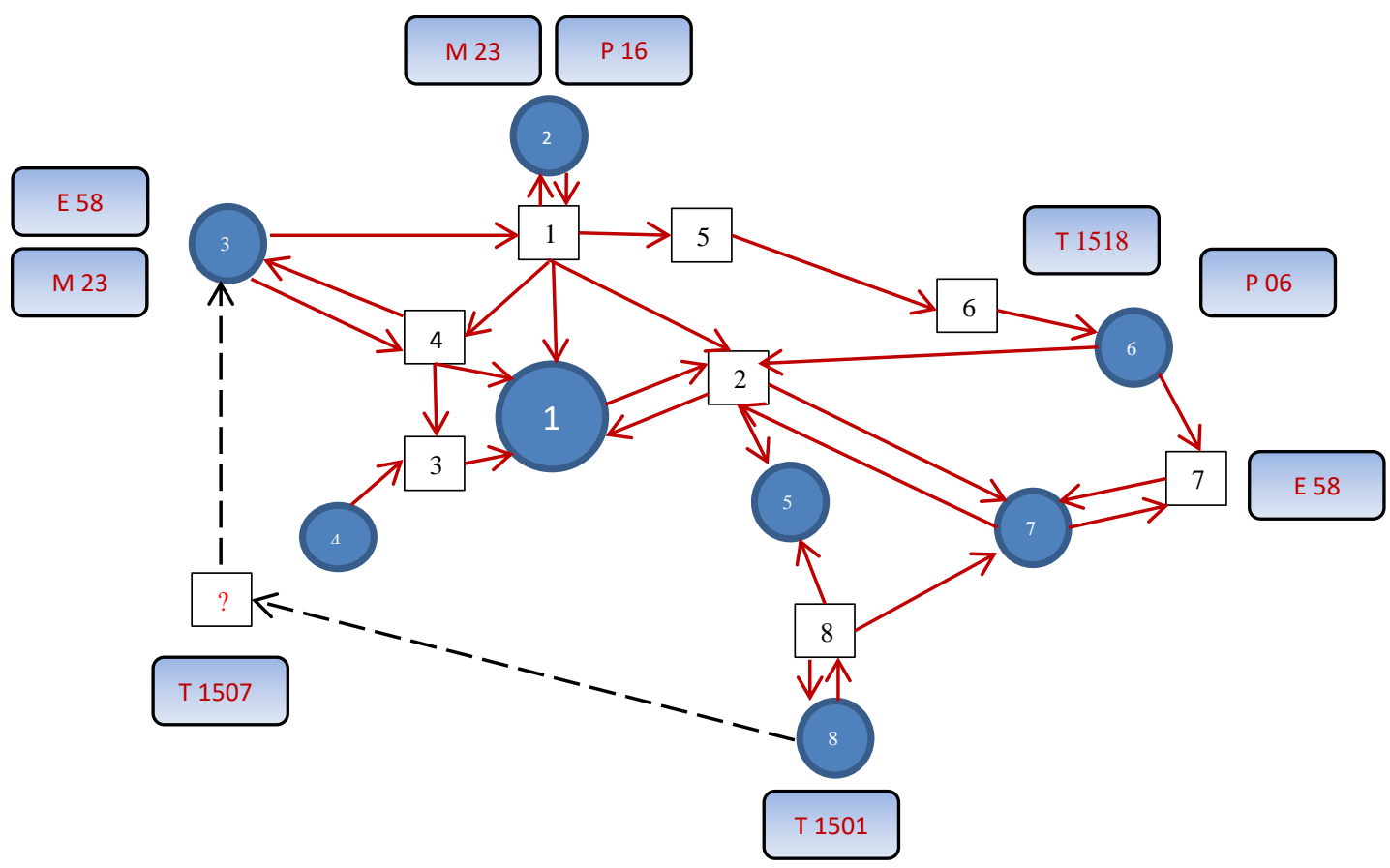

Fig. 7. The graph of the transport network in Mykolaiv.

Source: Compiled by the authors.

In the model considered, the edges of the graph are sections (races) of roads (streets) of urban, district or regional significance, which do not contain intersections, traffic lights and entrances and exits. It is assumed that the movement on these sections is limited only by the properties of the vertices that connect these edges and the parameters of the line. We will assume that the weight parameters of the edges do not change at this interval. Further, a vector is a set of independent line parameters between vertices $(i, j)$. Under the system of independent parameters we mean a set of such characteristics of an edge that cannot be expressed through others. Thus, with respect to the graph (Fig. 6), the components of the vector will be a set of matrices whose dimension is determined by the dimension of the connectedness matrix. Then to describe the transport-distributed system of the city this vector can be represented in the following form:

$$
R_{i j}=R\left(L_{i j}, P_{i j}, V_{i j}\right)
$$

where: $L_{i j}$ - matrix of lengths of sections (races) between vertices $(i, j)$;

$P_{i j}-$ matrix characterizing the capacity of the line from top i to top $\mathrm{j}$;

$V_{i j}$ - speed limit matrix on a given section of road /

These parameters are basic for this model in the sense that they can be considered constant over a considerable period of time. They can be used to calculate boundary characteristics for constraint matrix construction. For example, the minimum time interval of the vehicle on the line $(i, j)$ can be calculated by the formula:

$$
t_{i j}=L_{i j} / V_{i j}
$$

If we further introduce the parameters of filling the road with vehicles we will be able to calculate the maximum number of vehicles that can be on the road at a time. For this, suppose that $l_{k}, k=1, \ldots, r$ a set of dimensions of vehicles that carry out traffic in a settlement. And $r_{i j}^{k}-$ the probability that a vehicle is moving in the direction $(i, j)$, has dimensions $l_{k}$ Then the average length of the vehicle, taking into account the interval of movement $\Delta$, in the direction $(i, j)$ can be calculated by the formula:

$$
\bar{l}_{i j}=\frac{1}{r} \sum_{k=1}^{r} r_{i j}^{k} l_{k}+\Delta
$$

Accordingly, the maximum number of vehicles that can be on the highway $(\mathrm{i}, \mathrm{j})$ simultaneously

$$
g_{i j}=L_{i j} P_{i j} / \bar{l}_{i j}
$$

Similarly, you can enter many of the necessary parameters required to solve a specific problem.

\section{Conclusions}

1. Therefore, the analysis of the transport systems in Mykolaiv showed that it has a wide, powerful transport system, steady cargo and passenger flows and medium level of environmental pollution. According to these criteria, an approach is formulated in the paper that allows to set and solve the problems of forming and optimizing the functioning of urban transport systems. The presented set of algorithms allows to calculate the parameters of transport-ecological processes that are optimized. Based on the presented approach, it is possible to set the task of optimizing the traffic management functions on the basic network of transport highways with different degree of detail of municipal objects. This problem can be solved by dynamic 
programming and simulation methods.

2. Analysis of the road transport infrastructure and the strategic plan for the development of the city of Mykolaiv makes it possible to summarize the main measures that will contribute to the reduction of atmospheric emissions and improve the ecological condition of the city, namely: construction of a bridge over the Southern Bug River, in order to reduce the level of freight traffic through the historic city center ; improving the intersection of transport at the intersection of Zhovtnevy and railway stations, in the market area and the Ship district of Nikolaev on the Kherson highway by construction of bridges; laying a durable and high quality coating on the Ingulsky Bridge, through which the highway of international importance passes; construction of bypass roads and system of intermediate crossing points; development of alternative modes of transport including cycling.

\section{References}

1. Averkyna M. F. (2015). Features of formation of "green" logistic systems of the cities of Ukraine. Aktual'ni problemy ekonomiky. Vol. 1, 215-219.

2. Arhun Sch. V., Hnatov A. V., Ul'ianets O. A. (2016). Ecological and energy efficient road transport and its infrastructure. Visnyk Zhytomyrs'koho derzhavnoho tekhnolohichnoho universytetu. Seriia: Tekhnichni nauky. Vol. 2, 18-27.

3. Gnatov A. V., Argun Shch. V., Ul'yanets O. A. (2016). Energosberegayushchie tekhnologii na transporte. Naukovi notatki. Vol. 55. 80-86.

4. Hurch L. M. (2016). Transportation routing using the latest technologies. Visnyk Natsional'noho universytetu "L'vivs'ka politekhnika". Lohistyka. Vol. 846. 48-53.

5. Hurch L. M., Khmara L. Ye. (2014). Development of "green logistics in Ukraine. Visnyk Natsional'noho universytetu "L'vivs'ka politekhnika". Lohistyka. Vol. 811. 86-91.

6. Derzhavna sluzhba statystyky u Mykolaivs'kij oblasti. URL: http://www.mk.ukrstat.gov.ua.

7. Ofitsijnyj sajt Ministerstva infrastruktury Ukrainy. URL: http://www.mtu.gov.ua.

8. Stepanchuk O. V., Bieliatyns'kyj A. O. (2011). Negative impact of road transport emissions on the streets and roads of settlements. Problemy rozvytku mis'koho seredovyscha. Vol. 5-6. 224-229.

9. Bellekom S. (2012). Electric cars and wind energy: Two problems, one solution? A study to combine wind energy and electric cars in 2020 in The Netherlands Energy. Vol. 45. № 1. 859-866.

10. Gleissner H., Femerling J. C. (2014). Logistics: Basics - Exercises - Case Studies. Cham, Heidelberg, New York, Dordrecht, London. Springer. 311.

11. Greenhouse gas emissions from transport in Europe. (2019). European Environment Agency, Denmark 2019. 27.

12. Gromov V. (2014). Green Logistics in Russia (review article). Russian Journal of Logistics and Transport Management, Vol. 1. No 2. 36-44.
13. Xiaogang W., Chen H., Jingfu Ch. (2014). Energy Flow Chart-Based Energy Efficiency Analysis of a Range-Extended Electric Bus. Mathematical Problems in Engineering, Vol. 2014. 12.

14. Palanivelu P., Dhawan M. (2010). Green Logistics // TCS. URL: http://www.tcs.com/ Site Collec-ionDocuments/White\%20Papers/CPG_WhitePap er_Green_Logistics_08_2010.pdf.

15. Piecyk M., McKinnon A. (2010). Forecasting the carbon footprint of road freight transport in 2020. International Journal of Production Economics. 128, 3142.

16. Statistics. Data. (2018). $\mathrm{CO}_{2}$ Emissions from Fuel Combustion 2018. Highlights. International energy agency. OECD/IEA. 515.

\section{Список літератури}

1.Аверкина $M . \Phi$. Особливості формування "зелених" логістичних систем міст України . Актуальні проблеми економіки. 2015. № 1. С. 215219.

2.Аргун Щ. В., Гнатов А. В., Ульянец О. А. Екологічний та енергефективний автомобільний транспорт та його інфраструктура. Вісник Житомирського державного технологічного університету. Серія: технічні науки. 2016. № 2. С. 1827.

3.Гнатов А. В., Аргун Щ. В., Ульянеи О. А. Енергозберігаючі технології на транспорті. Луцьк: Наукові нотатки, 2016. С. 80-86.

4.Гурч Л. M. Маршрутизація перевезень 3 використанням новітніх технологій Вісник Національного університету "Львівська політехніка". Логістика. 2016. № 846. С. 48-53.

5.Гурч Л. М., Хмара Л. С. Розвиток "зеленої логістики" в Україні. Вісник Національного університету "Львівська політехніка". Логістика. 2014. № 811. С. 86-91.

6. Державна служба статистики у Миколаївській області. URL: http://www.mk.ukrstat.gov.ua.

7.Офіційний сайт Міністерства інфраструктури України. URL: http://www.mtu.gov.ua.

8.Степанчук O. В., Белятинський A. O. Негативний вплив викидів автомобільного транспорту на вулиці та дороги населених пунктів. Проблеми розвитку міського середовища. Вип. 5-6. 2011. C. 224-229.

9. Bellekom S. Electric cars and wind energy: Two problems, one solution? A study to combine wind energy and electric cars in 2020 in The Netherlands. Energy. 2012. T. 45. №. 1. P. 859-866.

10. Gleissner H., Femerling J. C. Logistics: Basics - Exercises - Case Studies. Cham, Heidelberg, New York, Dordrecht, London: Springer. 2014. 311 p.

11. Greenhouse gas emissions from transport in Europe. European Environment Agency, Denmark 2019. $27 \mathrm{p}$.

12. Gromov V. Green Logistics in Russia (review article). Russian Journal of Logistics and Transport Management. 2014. Vol. 1. No. 2. P. 36-44. 
13. Xiaogang W., Chen H., Jingfu Ch. Energy Flow Chart-Based Energy Efficiency Analysis of a RangeExtended Electric Bus Mathematical Problems in Engineering. 2014 [Електронний ресурс]. Режим доступу : http://dx.doi.org/10.1155/2014/972139.

14. Palanivelu P., Dhawan M. Green Logistics. TCS. URL: http://www.tcs.com/SiteCollection Docu ments/ White\%20Papers/CPG_WhitePaper_Green_ Logistics_08_2010.pdf.

15. Piecyk M., McKinnon A. Forecasting the carbon footprint of road freight transport in 2020. International Journal of Production Economics. 2010. Vol. 128. P. 3142.

16. Statistics. Data. $\mathrm{CO}_{2}$ Emissions from Fuel Combustion 2018. Highlights. International energy agency. OECD/IEA, 2018. 515 p.

\section{ПІДХОДИ ДО ОПТИМІЗАЦІЇ ФУНКЦІОНУВАННЯ ТРАНСПОРТНИХ СИСТЕМ МІСТ ЗА ЕКОЛОГІЧНИМИ КРИТЕРІЯМИ \\ О. М. Загурський, А. М. Огієнко}

Анотація. Питання ефективності транспортних систем $\epsilon$ одним із най актуальнійших питань сьогодення. Виконуючи свою функцію 3 переміщення вантажів та забезпечуючи різноманітні блага для економіки i населення, транспорт одночасно стає одним із джерел найсильнішого забруднювання навколишнього середовища. Відповідно основне завдання «зеленої» логістики полягає у збалансуванні екологічних і економічних проблем, у визначенні оптимальних рішення, за яких при незмінних (або близьких до них) витратах, шкода нанесена танспортом навколишньому середовищу буде зменшуватися.

В статті проведено дослідження фекторів, які впливають на ефективність транспортних систем міст, особливо з точки зору екологічної складової, та побудовано матиматичну модель, що дозволяє ставити i вирішувати завдання формування та оптимізації функціонування транспортних систем міст. Здійснена практична розробка комплексу алгоритмів що дають можливість розраховувати параметри транспорно-екологічних процесів, які оптимізуються 3 метою зменшення екологічного забруднення міста.

Вплив транспортного транспортного фактору на навколишне середовище міста розглянуто на прикладі міста Миколаїв, що має потужну систему транспорту, сталі вантажні та пасажирські потоки й середній рівень екологічного забруднення. Для комплексного вирішення транспорно-екологічних проблем міста застосовано підхід побудований на соснові методів динамічгого програмування та імітаційнного моделювання. Його застосування робить можливим ставити завдання оптимізації функцій управління рухом на базовій мережі транспортних магістралей 3 різним ступенем деталізації муніципальних об'єктів.

Ключові слова: економічність, екологічність, маршрутизація, оптимізація, шкідливі викіди.

\section{ПОДХОДЫ К ОПТИМИЗАЦИИ \\ ФУНКЦИОНИРОВАНИЯ ТРАНСПОРТНЫХ СИСТЕМ ГОРОДОВ ПО ЭКОЛОГИЧЕСКИМ КРИТЕРИЯМ \\ О. Н. Загурский, А. Н. Огиенко}

Аннотация. Вопрос эффективности транспортных систем является одним из самых актуальных вопросов современности. Выполняя свою функцию по перемещению грузов и обеспечивая различные блага для экономики и населения, транспорт одновременно становится одним из источников сильного загрязнение окружающей среды. Соответственно основная задача «зеленой» логистики заключается в сбалансировании экологических и экономических проблем, в определении оптимальных решений, в которых при неизменных (или близких к ним) расходах, нанесенный танспортом вред окружающей среде будет уменьшаться.

В статье проведено исследование факторов влияющих на эффективность транспортных систем городов, особенно с точки зрения экологической составляющей, и построено матиматичну модель, позволяющая ставить и решать задачи формирования и оптимизации функционирования транспортных систем городов. Осуществлена практическая разработка комплекса алгоритмов позволяющих рассчитывать параметры транспорно-экологических процессов, которые оптимизируются с целью уменьшения экологического загрязнения города.

Влияние транспортного транспортного фактора на окружающую среду города рассмотрено на примере города Николаев, имеющего мощную систему транспорта, устойчивые грузовые и пассажирские потоки и средний уровень экологического загрязнения. Для комплексного решения транспорно-экологических проблем города применен подход построеный на сосновые методов динамичгого программирования и имитацийнного моделирования. Его применение делает возможным ставить задачи оптимизации функций управления движением на базовой сети транспортных магистралей с различной степенью детализации муниципальных объектов.

Ключевые слова: экономичность, экологичность, маршрутизация, оптимизация, вредные выброса.

О. М. Загурський ORCID 0000-0002-5407-8466.

А. М. Огієнко ORCID 0000-0001-6491-6673. 
